\title{
Dorid nudibranchs described by J.E. Gray in M.E. Gray, 1842-1857 (Mollusca: Opisthobranchia)
}

\author{
Ángel Valdés ${ }^{1}$ and Shireen J. Fahey ${ }^{2}$ \\ Natural History Museum of Los Angeles County, 900 Exposition Boulevard, \\ Los Angeles, California 90007, U.S.A.(e-mail: avaldes(enhm.org) \\ :California Academy of Sciences, Department of Invertebrate Zoology and Geology, 875 Howard Street, \\ San Francisco, California 94103, U.S.A.(e-mail: sfahey@calacademy.org)
}

\begin{abstract}
In works completed during the years 1842-1857 J.E. Gray introduced four new generic and five specific names of dorid nudibranchs based on drawings reproduced by his wife M.E. Gray. Some of those names are currently in use, whereas others have not been in use since their introduction.

These names are revisited, along with reproductions of the original drawings by M.E. Gray, and a discussion of the status of the names. Photographs of likely representatives of these species are presented, based on our interpretation of the original description. Where there is some uncertainty, we have offered a discussion as to the most likely possibility of a correct identification. A list of potential changes that would have to be made during revision of the groups herein is included as a guide for succeeding authors.
\end{abstract}

\section{INTRODUCTION}

Maria Emma Smith Gray [1787-1876], conchologist and algologist, was the spouse of naturalist John Edward Gray [1800-1875]. Mrs. Gray greatly assisted her husband in his scientific work especially by her drawings. She also mounted and arranged most of the Cuming collection of shells in the British Museum (now The Natural History Museum, London), but she was mostly interested in the study of sponges and algae.

During the $1840^{\prime}$ s M.E. Gray had to spend a period of time confined at home due to health problems. During that time, she copied from several works figures of mollusks for the use of her husband. Hoping that other authors could also benefit from this compilation of figures, she decided to publish them in a series of volumes (E.M. Gray, 1842-1857). Although five volumes were published, only four concentrated on the Nudibranchia. In the fourth volume, J.E. Gray wrote an explanation of the plates. In most cases J.E. Gray copied the name of the species and included a reference to the work from which the drawings were copled. However, in some cases the drawings were copied from manuscript works and new names were introduced for the species. In some cases, authors used those new names, whereas others were either overlooked or ignored for unknown reasons by the malacological community

The objective of the present paper is to bring the researchers' attention to the importance of delving into the scientific literature to uncover and discuss the original name(s) and all synonymies of a species. We present a particularly troublesome example that demonstrates why such full checks should be performed. In addition, we wish to call the attention of modern nudibranch researchers to the names used by Gray, first as an interesting historical overview of how taxonomic names can come into use or fall into obscurity. Due to the lack of original material from which to compare photographs and live specimens to Gray's drawings, we have illustrated the species most closely resembling those drawings in order to inspire further interest in and debate on the history of nudibranch species names.

\section{SYSTEMATICS}

\section{Generic names}

Names are printed as in the original description (between quotation marks), and arranged in the original order. A complete reference is provided, including the type species and some remarks on the taxonomy or nomenclature of each genus name.

1. "ACANTHODORIS. Gill not retractile; tentacula retractile." - Acanthodoris J.E. Gray in M.E. Gray, 1850: 103.

\section{Type species}

Doris pilosa Abilgaard in Müller, 1789, by monotypy. 


\section{Remarks}

This generic name is currently regarded as valid.

2. "Ceratodoris. Tentacula enlongate, filiform, not retractile." - Ceratodoris J.E. Gray in M.E. Gray, 1850: 103.

\section{Type species}

Doris eolida Quoy and Gaimard, 1832, by monotypy.

\section{Remarks}

J.E. Gray (1842-1857) introduced the genus name Ceratodoris in combination with Doris eolida Quoy and Gaimard, 1832, which is the type species by monotypy. Quoy and Gaimard (1832: 263-264, pl. 18 , figs 11-15) described Doris eolida as a small white dorid with reddish spots and large dorsal processes. This description matches the characteristics of Okenia plana Baba, 1960, and it is most likely that these two names are synonyms. Therefore Ceratodoris is a junior synonym of Okenia Menke, 1830. Bergh (1874: 109-112, pl. 3, figs 4-20) introduced the genus Echinodoris Bergh, 1874 also based in Doris eolida Quoy and Gaimard, 1832. However, Bergh (1874) misidentified the type species of Echinodoris, and he actually described a specimen of Cadlinella ornatissima Risbec, 1928. Rudman (1995) provided a thorough discussion of the status of Ceratodoris eolida and this reference should be consulted for further details. We agree with Rudman (1995) in that the status of Echinodoris will remain undetermined until a type species is fixed for this genus name. Possibilities include either that Echinodoris is based on the nominal species previously cited as type species or it may be the taxonomic species actually involved in the misidentification (ICZN 1999: Article 70.3).

3. "Atagema. Gills very small, at the end of a dorsal sac." - Atagema J.E. Gray in M.E. Gray, 1850: 104.

\section{Type species}

Doris carinata Quoy and Gaimard, 1832, by monotypy.

\section{Remarks}

Valdés and Gosliner (2001) examined the single remaining syntype of Atagema carinata to confirm its identity and to compare to specimens for their study. These authors provided a diagnosis and discussion on the status and synonymy of Atagema, which is currently in use.

4. "Ceratosoma. Back produced behind." Ceratosoma J.E. Gray in M.E. Gray, 1850: 105.

\section{Type species}

Ceratosoma trilobata J.E. Gray, 1850, by monotypy.

\section{Remarks}

According to Rudman (1984), J.E. Gray's description is the original introduction of the genus Ceratosoma. Most authors attributed this genus to Adams and Reeve, 1850, but J.E. Gray's description appeared several months earlier. As Rudman (1984) pointed out, it is not possible to know the identity of Ceratosoma trilobata based on the two drawings published by M.E. Gray, or whether or not they represent the same species. The second drawing appears in volume 4 as "Doris trifida. Gray" which is probably an error for Doris trilobata.

\section{Specific names}

Names are printed between quotation marks, and arranged in the original order. Then the modern equivalent is provided, including a complete reference, the type locality, and some remarks on the taxonomy or nomenclature and etymology of each species. The original figures of each species are here reproduced and cited in the text.

1. "Glossodoris D'Orbignii, D'Orb. t. 216. f. 2." Glossodoris dorbignii J.E. Gray in M.E. Gray, 1850: 102, pl. 216, fig. 2 (Figure 1A).

\section{Type locality}

Unknown.

\section{Remarks}

The illustration reproduced by M.E. Gray appears to be copied from a d'Orbigny's unpublished work. The specimen figured has a series of rounded dorsal tubercles interconnected by low ridges (Figure 1A). There are two larger and more elongate tubercles on each rhinophoral sheath and 8 longer branchial leaves and 5 short leaves. Thompson (1984) illustrated the ventral surface of Doris sticta (Iredale and O'Donoghue, 1923) and the oral tentacles most nearly match those of Mrs. Gray's drawing showing digitform tentacles. The difference found between M.E. Gray's drawing and live animals of Doris sticta with the shorter 5 anterior branchial leaves of Glossodoris dorbignii is probably due to damage of the original specimen.

We also compared M. E. Gray's drawing with Doris verrucosa Linnaeus, 1758 because of the shape of the dorsal tubercles in Gray's drawing. However, this species does not have ridges between the dorsal tubercles and the size and placement of the tubercles (Rudman 2004) is not consistent with M. E. Gray's drawings. Her drawings show large tubercles situated on the dorsal median, with only small tubercles along the mantle margin. Doris verrucosa has large tubercles scattered over much of the dorsum. The dorsal tubercles of Glossodoris dorbignii are not all as mushroom-shaped as in Gray's drawings, but some tubercles do have this shape. 
The oral tentacles of $D$. verrucosa are also short whereas in both Gray's drawing and in Glossodoris dorbignii they are digitform and elongate.

Because of the external features listed above, it is clear that Glossodoris dorbignii is a member of the genus Doris Linnaeus, 1758 and a senior synonym of Doris sticta (Iredale and O'Donoghue, 1923). Doris sticto was originally introduced as a replacement name for Doris maculata Garstang, 1896, type locality Plymouth, England [not Doris Maculata Montagu, 1804 = Doto maculata; type locality Devonshire, England].

In the past fifty years, the following authors have used the specific name sticta as the valid name for this member of the genus Doris: Pruvot-Fol (1951, 1954), Gantès (1956), Nordsieck (1972), Bouchet and Tardy (1976), Cattaneo-Vietti and Barletta (1984) Thompson and Brown (1984), Perrone (1988), Thompson (1988), Cattaneo-Vietti and Thompson (1989), Cattaneo-Vietti, Chemello, and Giannuzzi (1990), Sabelli et al. (1990), Smith and Heppell (1991), Sabelli et al. (1992), Valdés (1992), Picton and Morrow (1994), Goto and Poppe (1996), Connor et al. (1997a, 1997b), Howson and Picton (1997), García-Gómez (2002), Hiscock et al. (2002), Valdés (2002b), Gavaia et al. (2003), Parr and Ager (2003), and Calado et al. (2005). The name dorbignit has not been used as valid since the original description.

According to the ICZN (1999, Article 23.9.2), a junior synonym takes precedence over a senior synonym that has not been used since 1899, if the junior synonym has been used in at least 25 publications, published by at least 10 authors in the immediately preceding 50 years. These conditions are met with the above referenced citations. Therefore the name Doris sticta is considered valid (nomen protectum) and Glossodoris dorbignii is considered invalid (nomen oblitum).

\section{Etymology}

This species (Glossodoris dorbignii) was named after Alcide Charles Victor Marie Dessalines d'Orbigny [1802-1857], prominent French naturalist. Between 1815 and 1820 he and his family lived at Esnandes, a coastal village $13 \mathrm{~km}$ north of La Rochelle, where his father Charles encouraged d'Orbigny's interest in marine life. During that time he collected various specimens of opisthobranchs now deposited at the Museum National d'Histoire Naturelle, Paris, France. It is likely that d'Orbigny encountered specimens of Doris sticta, which is relatively common in northern France. In 1826, at the age of 24, d'Orbigny was selected to sail for South America on a seven-year research expedition organized by the Museum National d'Histoire Naturelle. He amassed an enormous collection of natural history specimens. After returning to France, invertebrate fossils became d'Orbigny's main focus of interest, especially the taxonomy and stratigraphical distribution of species from the Jurassic and Cretaceous. D'Orbigny made major contributions to many scientific disciplines, including zoology, paleontology, geology, archeology, and anthropology.

2. "Actinodoris Tilesii, Tilesius, t. 230. f. 4." Actinodoris tilesii J.E. Gray in M.E. Gray, 1850: 102, pl. 230, fig. 4 (Figure 1B).

\section{Type locality}

Japan.

\section{Remarks}

The specimen figured by M.E. Gray (Figure 1B) has a dark background color with a paler line around the mantle and foot margins. There are probably 6 tripinnate branchial leaves, although this is not clear from the drawing. The rhinophores are perfoliate, elongate and dark with a paler apex.

Actinodoris tilesii is most likely a junior synonym of Dendrodoris fumata (Rüppell and Leuckart, 1830). Brodie et al. (1997) revised the systematics of $D$. fumata and Dendrodoris nigra (Stimpson, 1855), concluding that these two species show a remarkable external variability. (See also Brodie and Calado 2006). The drawing of $A$. tilesii however clearly matches the black form of $D$. fumata, which is characterized by having a black dorsum with no white spots and a marginal thin red line around the mantle (Figure 1B). Some dark specimens of $D$. nigra have a similar coloration, but the red line is submarginal and there are white spots on the dorsum (Brodie et al. 1997).

M.E. Gray did not indicate the locality in which A. tilesit was collected, but according to Krusenstern $(1810-14)$ the specimen was collected in Japan.

\section{Etymology}

This species was named after Wilhelm Gottlieb Tilesius von Tilenau (1769-1857), who accompanied the Krusenstern expedition during the first Russian circumnavigation, from 1803 to 1806 . After the Russian painter, Kurjlandzow, left the expedition in Kamchatka in 1804, Tilesius became responsible for recording interesting observations relating to the geography and natural history of the places they visited. He contributed many detailed designs for the illustrations in the Atlas that accompanied the three volumes of Krusenstern's account of the voyage.

3. "Actinodoris Krusensternii, Tilesins, t. 230. f. 5." - Actinodoris krusensternii J.E. Gray in M.E. Gray, 1850: 102, pl. 230, fig. 5 (Figure 1C).

\section{Type locality}

Japan. 


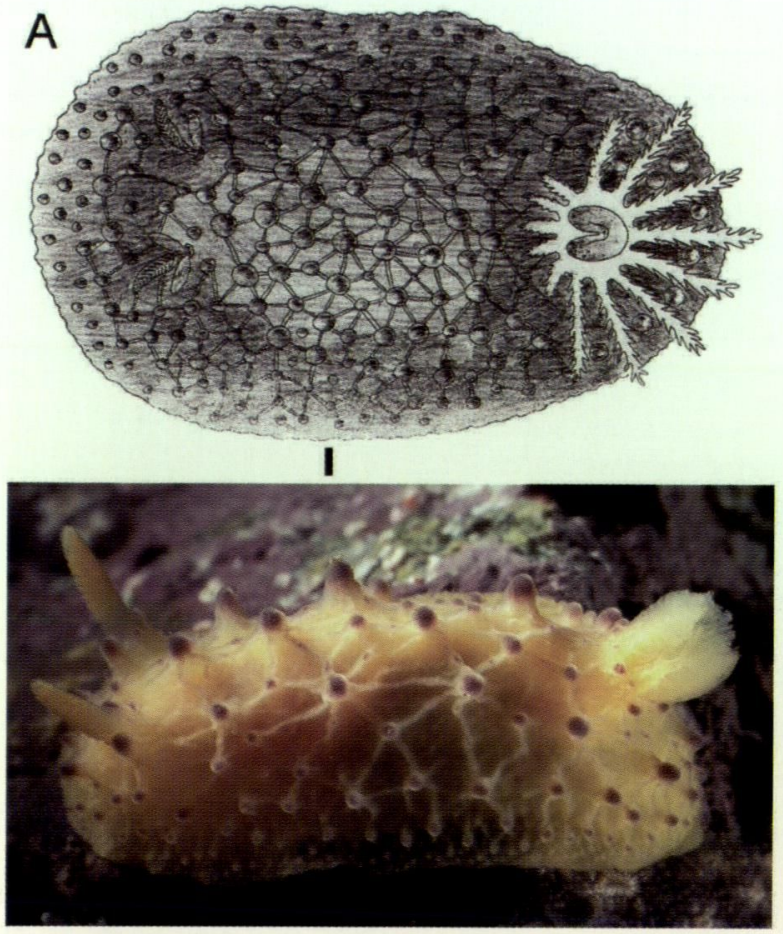

B
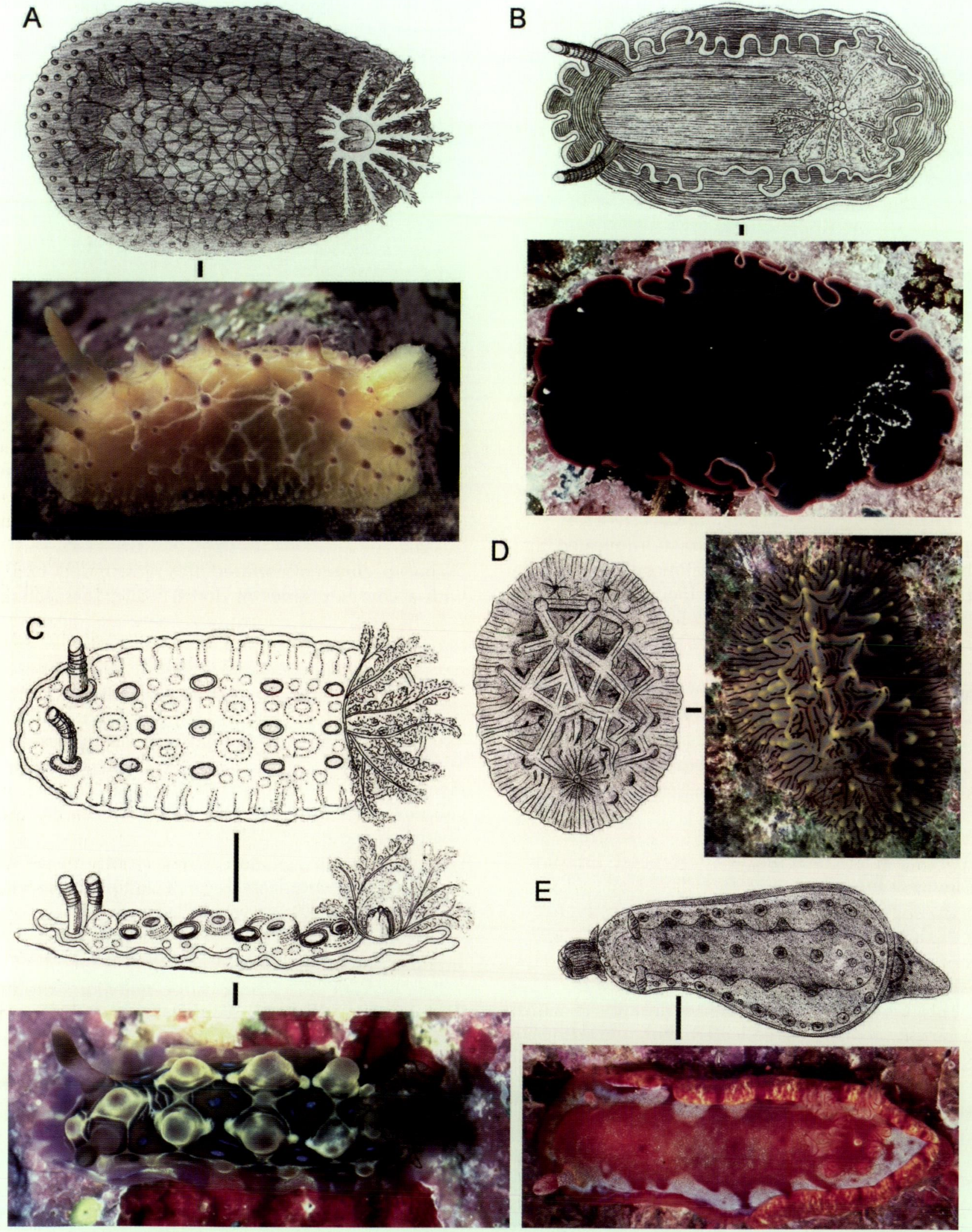

Figure 1 Figures reproduced by M.E. Gray and color photographs of the living animals. A, Glossodoris dorbignii J.E. Gray in M.E. Gray, 1850 and Doris sticta (Iredale and O'Donoghue, 1923) from Guernsey, Great Britain, photo and copyright Richard Lord. B, Actinodoris tilesii J.E. Gray in M.E. Gray, 1850 and Dendrodoris fumata (Rüppell and Leuckart, 1830) from Puerto Peñasco, Mexico, photo and copyright LACM archives. C, Actinodoris krusensternii J.E. Gray in M.E. Gray, 1850 and Dendrodoris denisoni (Angas, 1864) from Papua New Guinea, photo and copyright Terrence M. Gosliner. D, Doris incei J.E. Gray in M.E. Gray, 1850 and Halgerda willeyi Eliot, 1903 from Papua New Guinea, photo and copyright Terrence M. Gosliner. E, Hexabranchus adamsii J.E. Gray in M.E. Gray, 1850 and Hexabranchus sanguineus (Rüppell and Leuckart, 1830) from the Philippines, photo and copyright Ángel Valdés. 


\section{Remarks}

The figures by M.E. Gray depict an oval to elongate dorid, covered with rounded tubercles having what appear to be a central depression (Figure 1C). There are a series of oval markings on the dorsum; some of the markings are dark rings whereas others appear to be light rings and spots. The mantle margin is surrounded by a light line with radial inward ramifications that appear to fade out after running a short distance. There is an undetermined number of tripinnate branchial leaves and the rhinophores are elongate and perfoliate. Examination of the original drawings published by Kruzenstern (1810-14: pl. 61, figs. 14) show no additional details, with the exception of figure 2, which is a drawing of the ventral side of the body with the mouth area visible as a pore with no oral tentacles.

According to the external features and color pattern, Actinodoris krusensternii is most likely a senior synonym of Dendrodoris denisoni (Angas, 1864). Examination of photographs from living specimens of $D$. denisoni (Figure 1C) revealed that this species has a similar general morphology to the drawings of $A$. krusensternii, including a similar arrangement of the dorsal tubercles. Additionally, the tubercles of some specimens of $D$. denisoni have darker apices, giving them the appearance of being concave. The other markings and rings depicted by Tilesius (in Krusenstern) and M.E. Gray are most likely an attempt to reproduce the complex color pattern of $D$. denisoni. The presence of a reduced mouth area with no oral tentacles confirms that this is a species of Dendrodoris.

We realize that there are other names given to specimens of Dendrodoris denisoni such as $D$. clavalata (Alder and Hancock, 1864). However, as discussed by Brodie (2002), a complete revision of the clade Dendrodoris is needed at which time a thorough investigation should be undertaken on the synonyms of this species.

M.E. Gray did not indicate the locality in which A. krusensternii was collected, but according to Krusenstern (1810-14) the specimen was collected in Japan.

\section{Etymology}

This species was named after Adam Johann Ritter von Krusenstern also known as Ivan Fedorovich Kruzenshtern [1770-1846], and Krusenshtern (depending on the translation). He was a Russian navigator who circumnavigated the globe from 1803 to 1806 on the ships Nadezhda and Neva. Although the voyage was undertaken to stimulate the fur trade of the Pacific coast, to examine California for a possible colony, and to revive trade with China and Japan, its most important contribution was to investigate the hydrography of the North Pacific coast of America. His scientific work won him a honorary membership in the Russian Academy of Sciences. Krusenstern was director of the Royal Naval Academy and was promoted to the rank of admiral. He wrote an account of his voyage (Kruzenshtern, 1810-1814).

4. "Doris incii, Alder, MSS. t. 226. f. 1." - Doris incii J.E. Gray in M.E. Gray, 1850: pl. 226, fig. 1 (Figure 1D).

\section{Type locality}

Torres Straits, New Guinea.

\section{Remarks}

M.E. Gray's illustration reproduces a manuscript drawing by "Mr. Alder" of a specimen collected from Torres Straits, New Guinea. The authorship of the drawing is unknown because the identity of "Mr. Alder" could not be verified. As far as we know Joshua Alder [1792-1867] never traveled to New Guinea and no other naturalist or ship surgeon with this name served in survey ships in this region.

The specimen illustrated has a rounded body with a complex series of dorsal ridges connecting rounded tubercles (Figure 1D). There are numerous darker radial lines around the mantle margin and some on the center of the ridges. The rhinophores and gill appear to be retracted but the gill is multileaved. The characteristics of this animal most closely match the description or illustration of Halgerda willeyi by these authors: Eliot (1904), Burn (1975), Rudman (1978), Willan and Coleman (1984), Coleman (1989), Yonow (1990), Yonow and Hayward (1991), Debelius (1996), Willan (1998), Gosliner, Behrens and Williams (1996), Marshall and Willan (1999), Fahey and Gosliner (1999), Ono (1999), Carlson and Hoff (2000), Fahey and Gosliner (2000) Fahey and Gosliner (2001a), Fahey and Gosliner (2001b), Coleman (2001), Keiu (2000), Fahey and Gosliner (2003), Fahey and Healy (2003), Fahey 2003a), (Fahey 2003b), Ferrari and Ferrari (2003), Nakano (2004) and Ono (2004).

We also compared Gray's drawing to another externally similar species Halgerda elegans Bergh, 1905. However, that species has a very sparsely pinnate gill unlike the gill depicted by Gray. Also $H$. elegans does not have prominent dorsal tubercles at the juncture of each ridge.

According to the ICZN (1999, Article 23.9.2), a junior synonym takes precedence over a senior synonym that has not been used since 1899, if the junior synonym has been used in at least 25 publications, published by at least 10 authors in the immediately preceding 50 years. These conditions are met with the above referenced citations. Therefore the name Halgerda willeyi is considered valid (nomen protectum) while Doris incii is considered invalid (nomen oblitum). 


\section{Etymology}

This species was probably named after John Matthew Robert Ince [1808-1850] of the Royal Navy. (See Gray's text: "Doridae. Mr. Alder's MS drawing. From Torres Straits, Capt. Ince, R.N."). He served as lieutenant aboard the HMS Fly from 1841-1846, during the survey and mapping expeditions to the Torres Straits, along with naturalist Joseph Beete Jukes [1811-1869].

5. "Hexabranchus Adamsii, Adams, MSS. t. 219. f. 1." - Hexabranchus adamsii J.E. Gray in M.E. Gray, 1850: pl. 219, fig. 1 (Figure 1E).

\section{Type locality}

Borneo.

\section{Remarks}

The specimen figured by M.E. Gray has characteristics of Hexabranchus sanguineus (Rüppell and Leuckart, 1830). The 5 branchial leaves are contracted but visible near the posterior end of the dorsum (Figure 1D). The buccal mass is partially evaginated so that the mouth area and oral tentacles are visible emerging from the anterior end of the notum. The oral tentacles do not show the characteristic lobules present in species of Hexabranchus, but this is probably due to the angle in which they were drawn. The dorsal pattern of colors is very similar to the specimen of $H$. sanguineus also illustrated in Figure 1D.

There is no doubt that $H$. adamsii is a junior synonym of $H$. sanguineus, a fact that has been previously documented in the literature (Valdés 2002a). The drawing was copied from a manuscript picture by Arthur Adams.

\section{Etymology}

This species was named after Arthur Adams [1820-1878], who was the ship's surgeon on the H.M.S. Samarang expedition to East and South East Asia from 1843-1846, commanded by Captain Edward Belcher [1799-1877]. During the expedition Adams made numerous observations on living mollusks, sketching many of them in living state.

\section{DISCUSSION}

This discussion of nudibranch names introduced by J.E. Gray in M.E. Gray (1842-1850) has limited impact in current taxonomy of dorid nudibranchs. New provisions in the latest version of the International Code of Zoological Nomenclature (ICZN 1999: Article 23.9.1) allow the replacement of senior synonyms by junior synonyms if certain conditions are met. We have noted the names Doris sticta and Halgerda willeyi, both which would meet the conditions of Article 23.9.1.
The objective of this paper is to bring the researchers' attention to the importance of delving into the scientific literature to uncover and discuss the original name(s) and synonymies of a species. We have presented two particularly troublesome examples that demonstrate why such full checks should be undertaken. We are not proposing any changes in classification, because this subject is more appropriately addressed during revisionary work on each particular group. However, a list of potential changes that would have to be made is included in the summary below, of name statuses as a guide for other authors. Revisions of these groups and subsequent discussion of species names are encouraged and anticipated.

\section{Summary of genus name statuses}

- Acanthodoris J.E. Gray in M.E. Gray, 1850: 103, valid.

- Ceratodoris J.E. Gray in M.E. Gray, 1850: 103, junior synonym of Okenia Menke, 1830.

- Ceratosoma J.E. Gray in M.E. Gray, 1850: 103, valid.

- Atagema J.E. Gray in M.E. Gray, 1850: 104, valid.

\section{Summary of species name statuses}

- Glossodoris dorbignii J.E. Gray in M.E. Gray, 1850: 102, pl. 216, fig. 2, (nomen oblitum) Doris sticta (Iredale and O'Donoghue, 1923) (nomen protectum).

- Actinodoris tilesii J.E. Gray in M.E. Gray, 1850: 102, pl. 230, fig. 4, junior synonym of Dendrodoris fumata (Rüppell and Leuckart, 1830).

- Actinodoris krusensternii J.E. Gray in M.E. Gray, 1850: 102, pl. 230, fig. 5, senior synonym of Dendrodoris denisoni (Angas, 1864).

- Doris incei J.E. Gray in M.E. Gray, 1850: pl. 226, fig. 1 (nomen oblitum)

- Halgerda willeyi Eliot, 1903 (nomen protectum).

- Hexabranchus adamsii J.E. Gray in M.E. Gray, 1850: pl. 219, fig. 1, junior synonym of Hexabranchus sanguineus (Rüppell and Leuckart, 1830).

\section{ACKNOWLEDGEMENTS}

This research was partially funded by NSF PEET grant DEB 9978155 "Phylogenetic Systematics of Dorid Nudibranchs" to T. Gosliner and A. Valdés.

\section{REFERENCES}

Bergh, R. (1874). Neue Nacktschnecken der Südsee, malacologische Untersuchungen. 2. Journal des Museum Godeffroy 2: 91-116, pls. 1-4.

Bouchet, P. and Tardy, J. (1976). Faunistique et biogéographie des nudibranches des côtes Françaises de l'Atlantique et de la Manche. Annales de l'Institut Océanographique, Nouvelle Séries 52: 205-213. 
Brodie, G.D. (2002). The molluscan nudibranch Family Dendrodorididae (Anthobranchia: Doridoidea) in Australia: Systematics and phylogenetic relationships. Ph.D. Thesis. James Cook University, Townsville.

Brodie, G.D., Willan, R.C., and Collins, J.D. (1997). Taxonomy and occurrence of Dendrodoris nigra and Dendrodoris fumata (Nudibranchia: Dendrodorididae) in the Indo-West Pacific Region. Journal of Molluscan Studies 63: 407-423.

Brodie, G.D., and Calado, G. (2006). Dendrodoris arborescens (Collingwood, 1881) (Mollusca: Nudibranchia): larval characteristics reveal a masked porostome species. Records of the Western Australian Museum Supplement 69: 119-126.

Burn, R.F. 1975. A list of the dorid nudibranchs of Australia (Gastropoda, Opisthobranchia). pp. 514517. Appendix. [In] Thompson, T.E. 1975. Dorid nudibranchs from eastern Australia (Gastropoda, Opisthobranchia). Journal of Zoology 176: 477-517, pl. 1 ; figs. 1-6.

Calado, G.P., Malaquias, M.A.E., Gavaia, C., Cervera, J.L., Megina, C., Dayrat, B., Camacho-García, Y., Pola, M. and Grande, C. (in press). New data on opisthobranchs (Mollusca; Gastropoda) from the southwestern coast of Portugal. Boletin Del Instituto Español De Oceanografia.

Carlson, C. and Hoff, P. (2000). Three new Pacific species of Halgerda (Opisthobranchia: Nudibranchia: Doridoidea). The Veliger 43: 154-163.

Cattaneo-Vietti, R., Chemello, R., and Giannuzzi, R. (1990). Atlas of Mediterranean Nudibranchs. [Atlante dei Nudibranchi del Mediterraneo]. La Conchiglia: Rome.

Cattaneo-Vietti, R. and Thompson, T. E. (1989). Mediterranean opisthobranch molluscs: A zoogeographic approach. Bollettino Malacologico 25: 183-204.

Cattaneo-Vietti, R., and Barletta, G. (1984). Elenco preliminare dei molluschi opistobranchi viventi nel Mediterraneo (Sacoglossa, Pleurobranchomorpha, Acochlidiacea, Aplysiomorpha, Nudibranchia). Bollettino Malacologico (Pubblicazione Mensile Edita dalla Societa Italiana di Malacologia) 20: 195-218.

Coleman, N. (1989). Nudibranchs of the South Pacific. Australian Marine Photographic Index, Springwood, Australia.

Coleman, N. (2001). 1001 Nudibranchs. Australian Marine Photographic Index, Springwood, Australia.

Connor, D.W., Brazier, D.P., Hill, T.O., and Northen, K.O. (1997). Marine Nature Conservation Review: marine biotope classification for Britain and Ireland. Vol. 1. Littoral biotopes. Version 97.06. Joint Nature Conservation Committee Report, No. 229.

Connor, D.W., Dalkin, M.J., Hill, T.O., Holt, R.H.F., and Sanderson, W.G. (1997). Marine Nature Conservation Review: marine biotope classification for Britain and Ireland. Vol. 2. Sublittoral biotopes. Version 97.06. Joint Nature Conservation Committee Report, No. 230.

Debelius, H. (1996). Nudibranchs and Sea Snails, IKANUnterwasserarchiv, Frankfurt, Germany.

Eliot, C. (1904). On some nudibranchs from east Africa and Zanzibar, part III. Dorididae Cryptobranchiatae,
I. Proceedings of the Zoological Society of London 1903: 354-385, Pls. 32-34.

Fahey, S.J. and Gosliner, T.M. (1999). Preliminary phylogeny of Halgerda (Nudibranchia: Halgerdidae) from the tropical Indo-Pacific, with descriptions of three new species. Proceedings of the California Academy of Sciences 51: 425-448.

Fahey, S.J. and Gosliner, T.M. (2000). New records of Halgerda Bergh, 1880 (Opisthobranchia, Nudibranchia) from the deep western Pacific Ocean, with descriptions of four new species. Zoosystema 22: $471-498$.

Fahey, S.J. and Gosliner, T.M. (2001a). The phylogeny of Halgerda (Opisthobranchia, Nudibranchia) with the description of a new species from Okinawa. Zoologica Scripta 30: 199-213.

Fahey, S.J. and Gosliner, T.M. (2001b). On the genus Halgerda (Nudibranchia: Halgerdidae) from Western Australia with descriptions of four new species. Bollettino Malacologico, (Pubblicazione Mensile Edita dalla Societa Italiana di Malacologia) 37: 55-76.

Fahey, S.J. and Gosliner, T.M. (2003). Redescription of Halgerda graphica Basedow and Hedley, 1905 with observations on external morphological variation within selected species of Halgerda (Mollusca, Nudibranchia) Proceedings of the California Academy of Sciences 54: 393-406.

Fahey, S.J. and Healy, J.M. (2003). Sperm ultrastructure in the nudibranch genus Halgerda with reference to other Discodorididae and to Chromodorididae (Mollusca: Opisthobranchia). Journal of Morphology 257: 9-21.

Fahey, S.J. (2003). Combining traditional morphological character sets with molecular, sperm ultrastructure and biochemical data. Can this improve an evolutionary model? Ph.D. Thesis. University of Queensland, Brisbane.

Fahey, S.J. (2003). Phylogeny of Halgerda (Mollusca: Gastropoda) based on combined analysis of mitochondrial COI and morphology. Invertebrate Systematics 17: 617-624.

Ferrari, A. and Ferrari, A. (2003). A diver's guide to underwater Malaysia macrolife. Nautilus Publications, Sabah.

Gantès, H. (1956). Complément à l'étude des opisthobranches des côtes du Maroc. Bulletin de la Société des Sciences Naturelles et Physiques du Maroc 36: 257-263.

García-Gómez, J.C. (2002). Paradigmas de una Fauna Insólita: Los Moluscos Opistobranquios del Estrecho de Gibraltar. Instituto de Estudios Campogibraltareños, Algeciras, Cádiz.

Gavaia, C., Malaquias, M. A. E., Calado, G., and Urgorri, V. (2003). New records of Portuguese opisthobranch molluscs. Journal of Conchology 38: 101-118.

Gray, M.E. (1842-1850). Figures of molluscous animals, selected from various authors. Etched for the use of students. Longman, Brown, Green and Longmans, London. Dates of publication: vol. 1, pls. 1-78 [1842], vol. 2, pls. 79-199 [1850]; vol. 3, pls. 200-312 [1850]; vol. 4, pp. 1-124 [1850]; vol. 5, Brachiopoda [1857].

Gosliner, T., Behrens, D. and Williams, G. (1996). Coral Reef Animals of the Indo-Pacific: Animal Life from Africa 
to Hawaii Exclusive of the Vertebrates. Sea Challengers, Monterey, USA.

Goto, Y. and Poppe, G. (1996). A listing of living molluscs. Part I, Vol. II. Ancona, Italy.

Hiscock, K; Tyler-Walters, H. and Jones, H. (2002) High level environmental screening study for offshore wind farm developments-marine habitats and species. Report for the Department of Trade and Industry, Plymouth UK.

Howson, C.M. and Picton, B.E. (eds). (1997). The Species Directory of the Marine Fauna and Flora of the British Isles and Surrounding Seas. Ulster Museum, Belfast.

ICZN. (1999). International Code of Zoological Nomenclature, Fourth Edition. International Trust for Zoological Nomenclature, London.

Keiu, S. (2000). Opisthobranchs of Izu Peninsula. TBSBrittanica Co., Ltd., Tokyo, Japan.

Kruzenshtern, I.F. (1810-1814). Reise um die Welt in den Jahren 1803, 1804, 1805 und 1806 auf Befehl seiner Kaiserlichen Majestät Alexander des Ersten auf den Schiffen Nadeshda und Newa unter dem Caommando des Capitains von der Kaiserlichen Marine A.J. von Krusenstern [German translation of the original Russian edition published at St. Petersburg in 18091814]. Schnoorsche Buchdr.: St. Petersburg. Dates of publication: vol. 1 [1810], vol. 2 [1811], vol. 3 [1812], atlas [1814].

Marshall, J.G. and Willan, R.C. (1999). Nudibranchs of Heron Island, Great Barrier Reef. Backhuys Publishers, Leiden.

Nakano, R. (2004). Opisthobranchs of Japan Islands. TBSBrittanica Co., Ltd., Tokyo.

Nordsieck, F. (1972). Die Europäischen Meeresschnecken (Opisthobranchia mit Pyramidellidae; Rissoacea). Gustav Fischer Verlag, Stuttgart.

Ono, A. (1999). Opisthobranchs of Kerama Island. TBSBrittanica Co., Ltd., Tokyo.

Ono, A. (2004). Opisthobranchs of Ryukyu Islands. TBSBrittanica Co., Ltd., Tokyo.

Quoy J. and Gaimard J. (1832-1833). Zoologie: 1-686, pls 1-26, in Dumont d'Urville J. S. C. (ed.), Voyage de découtvertes de "l'Astrolabe" exécuté par ordre du Roi, pendant les années 1826-1827-1828-1829, sous le commandement de $M$. J. Dumont d'Urville, vol. 2 and Atlas. Tastu: Paris. Dates of publication: pp. 1-320 [1832], 321-686 [1833], pls. 1-26 [1833].

Parr, J, and Ager, O.E.D. 2003. Collation of data on distribution of species and habitats in the Irish Sea. Report from the Marine Biological Association to the Joint Nature Conservation Committee, JNCC Contract: F90-01592.

Perrone, A. (1988). Una specie di nudibranchi doridiani nuova per il Mediterraneo: Dati sulla morfologia di Doris bertheloti (D'Orbigny, 1839) (Opisthobranchia: Nudibranchia). Bollettino Malacologico 24: 237-242.

Picton, B. E. and Morrow, C. (1994). A Field Guide to the Nudibranchs of the British Isles. Immel Publishing: London.

Pruvot-Fol, A. (1951). Études des nudibranches de la Méditerranée (2 Partie). Archives de Zoologie Expérimentale et Générale 88: 1-80, pls. 1-4.
Pruvot-Fol, A. 1954. Mollusques Opisthobranches. Faune de France 58: 1-460.

Rudman, W.B. (1978). The dorid opisthobranch genera Halgerda Bergh and Sclerodoris Eliot from the IndoWest Pacific. Zoological Journal of the Linnean Society 62: 59-88, pl. 1.

Rudman, W.B. (1984). The date and authorship of Bornella and Ceratosoma (Nudibranchia) and other Molluscs collected during the Voyage of H.M.S. Samarang, 1843-46. Malacological Review 17: 103-104.

Rudman, W.B. (1995). The Chromodorididae (Opisthobranchia: Mollusca) of the Indo-Pacific: further species from New Caledonia and the Noumea romeri color group. Molluscan Research 16: 1-43.

Rudman, W.B. (2004). SeaSlug Forum. Accessed July 2004. http:/ / www.seaslugforum.net

Sabelli, B. Giannuzzi-Savelli, R. and Bedulli, D. (1990). Catalogo annotato dei Molluschi marini del Mediterraneo. Vol. 1. Società Italiana di Malacologia, Bologna.

Sabelli, B. Giannuzzi-Savelli, R. and Bedulli, D. (1992). Catalogo annotato dei Molluschi marini del Mediterraneo. Vol. 2. Società Italiana di Malacologia, Bologna.

Smith, E.A. and Heppell, D. (1991). Check list of British Marine Mollusca. National Museums of Scotland, Edinburgh.

Thompson, T.E. (1988). Molluscs: Benthic Opisthobranchs (Mollusca: Gastropoda). Brill and Backhuys, Leiden.

Thompson, T.E. and Brown, G.H. (1984). Biology of Opisthobranch Molluscs, Vol. II. The Ray Society, London.

Valdés, A. (1992). Nuevas aportaciones al conocimiento de los opistobranquios del litoral Asturiano. Boletín de Ciencias Naturales del Real Instituto de Estudios Asturianos 42: 21-38.

Valdés, A. (2002a). How many species of Hexabranchus are there? Molluscan Research 22: 289-301.

Valdés, A. (2002b). A phylogenetic analysis and systematic revision of the cryptobranch dorids (Mollusca, Nudibranchia, Anthobranchia). Zoological Journal of the Linnean Society 136: 535-636

Valdés. A. and Gosliner, T. (2001). Systematics and phylogeny of the caryophyllidia-bearing dorids (Mollusca, Nudibranchia), with descriptions of a new genus and four new species from Indo-Pacific deep waters. Zoological Journal of the Linnean Society 133: 103-198.

Willan, R. (1998). Opisthobranchia. In P.L. Beesley, G.J. Ross and A. Wells, (eds), Mollusca the Southern Synthesis. Part B. Fauna of Australia Volume 5. CSIRO, Canberra.

Yonow, N. (1990). Red Sea Opisthobranchia. 3. The orders Sacoglossa, Cephalaspidea, and Nudibranchia: Doridacea (Mollusca, Opisthobranchia). Fauna of Saudi Arabia 11: 286-299.

Yonow, N. and Hayward, P. (1991). Opisthobranches de l'Ile Maurice, avec la description de deux espèces nouvelles (Mollusca: Opisthobranchia). Revue Française d'Aquariologie 18: 1-30. 